The Effect of Sewage Sludge Applications on the Growth of Maize (Zea mays L.) and Some Soil Properties

\author{
Huda Nur ÇAKIR ${ }^{1}$, Kerim Mesut ÇİMRIN 2 \\ Mustafa Kemal University, Faculty of Agriculture, Department of Soil Science and Plant Nutrition, 31034, Hatay/Turkey \\ ${ }^{1}$ https://orcid.org/0000-0003-4219-9663, ${ }^{2}$ https://orcid.org/0000-0001-5158-8412 \\ 凹: mcimrin@hotmail.com
}

\begin{abstract}
The aim of this study is to investigate the existing changes for corn yield with the changes on the soil properties after the applications of increased sewage sludge (SS $0 \%, 2.5 \%, 5 \%, 7.5 \%, 10 \%$ ). While statistically significant decreases were determined in the $\mathrm{pH}$ and lime contents of the experimental soil, there were also statistically significant increases for the contents of organic matter and salt of the soil by the effects of applied sewage sludge at the increased doses. The applications statistically increased corn fresh and dry root weights, fresh and dry shoot weights, plant height and diameter compared to the control in the all treatments. It can be concluded that that sewage sludge is not appropriate to use in the agricultural soils in the present form because of very high salt amounts presence in the sewage sludge although there were some positive effects on the plant and soil properties to some great extent with no determined heavy metal toxicity by the application of that sewage sludge into soil at different rates taken freshly from the biological sewage sludge foundation of district İskenderun of province Hatay.
\end{abstract}

Research Article
$\begin{array}{ll}\text { Article History } \\ \text { Received } \quad: 02.10 .2019 \\ \text { Accepted } \quad: 19.11 .2019\end{array}$

Keywords
Soil properties
Sewage sludge
Corn
Yield

\title{
Kentsel Arıtma Çamuru Uygulamalarının Mısır Bitkisinin (Zea mays L.) Gelişimi ve Bazı Toprak Özellikleri Üzerine Etkisi
}

\section{ÖZET}

Bu çalışmanın amacı, artan arıtma çamuru (\% 0, \% 2.5, \% 5, \% 7.5, $\%$ 10) uygulamaları sonrası misır bitkisinin verim ve deneme toprağının bazı özellikleri üzerindeki değişimler ile mısır bitkisinin, kök ve kök üstü kısımları ile bitki boyu ve çapında meydana gelen değişimleri incelemektir.Artan dozda uygulanan arıtma çamurunun etkisiyle deneme toprağının $\mathrm{pH}$ ve kireç içeriklerinde istatistiki açıdan önemli azalmalar belirlenirken, toprağın tuz, organik madde içeriklerinde ise istatistiki açıdan önemli artışlar meydana gelmiştir. Uygulamalar mısır bitkisinin kök yaş ve kuru ile kök üstü yaş ve kuru verimleri, bitki boyu ve bitki çapını tanığa göre tüm uygulamalarda istatistiki açıdan önemli olarak arttırmıştır. Sonuç olarak, Hatay ili İskenderun ilçesi Biyolojik arıtma tesisinden taze alınan arıtma çamurunun farklı oranlarda toprağa uygulaması ile her ne kadar bazı bitki ve toprak özelliklerine olumlu etkilerinin bulunmasına rağmen bu arıtma çamurunda bulunan çok yüksek tuz miktarları nedeniyle, bu haliyle tarım topraklarında kullanılmasının uygun olmadığı söylenebilir.

\section{Araştırma Makalesi}

$\begin{array}{ll}\text { Makale Tarihçesi } \\ \text { Geliş Tarihi } & : 02.10 .2019 \\ \text { Kabul Tarihi } & : 19.11 .2019\end{array}$

Anahtar Kelimeler

Toprak özellikleri

Arıtma çamuru

Misir

Verim

To Cite : Çakır HN, Çimrin KM 2020. The Effect of Sewage Sludge Applications on the Growth of Maize (Zea mays L.) and Some Soil Properties. KSU J. Agric Nat 23 (2): 321-327. DOI: 10.18016/ksutarimdoga.vi.565751.

\section{INTRODUCTION}

Urban sewage purification systems and municipal waste water treatment plants hold a place as a reciprocal response for sewage sludge come out. Various methods such as storing, burning, discharging to the sea and using in agricultural land are applied for the disposal of these sewage sludge. However, most of these methods are temporary solutions, and when uncontrolled conditions return to the soil, mainly by the dynamics of the environmental conditions, the consequent risks take place for food chain resulting from the contamination of soil, groundwater and 
plants. Recently, it has become more and more important to apply the sludges into agricultural land and to evaluate the soil as a source of organic matter and plant nutrients (Çimrin et al. 2000; Demir and Çimrin, 2011; Yalçın et al. 2011). When these wastes are involved into the soil in appropriate quantities and proportions under controlled conditions, there will be alternative or having sustaining effect for the commercial fertilizers resulting from the content differences (Çimrin et al. 2000; Angın and Yağanoğlu 2009; Yalçın ve ark., 2011).

The application of sewage sludge can improve the physical and chemical properties of the soil and increase its efficiency but the salt and heavy metal content of the treated sewage sludge may affect the soil and environment health negatively. Thus, different properties of the sludge originated from the different materials can alter the effects on the treated soil and the yield and their usage possibilities. The treated sludges must be analyzed and their contents determined before applying into the soil, and for this reason, it is necessary to determine the most appropriate, if necessary, doses by testing different treated sludges in different soil.

The aim of this study is to determine the effects on the plant corn grown on the agricultural soil by the application of freshly treated sewage sludge obtained from the biological municipal wastewater treatment plant of the district İskenderun of province Hatay.
The soil used in the study is placed district of Reyhanl in province of Hatay called as Gazimürsel hill surface soil. The sewage sludge used in the study was brought to the laboratory on the same day after putting into plastic bag freshly from the production facility of Iskenderun Municipality biological domestic wastewater treatment plant. Soil and sludge brought to the laboratory were first used after air drying under shade. In the study, Pioneer 1570 summer hybrid seed of plant corn (Zea mays L.) with $99 \%$ germination rate was used as plant material.

According to Jackson (1958) the textures were prepared for the analysis and determined according to Bouyoucous (1951), in soil and sludge the reaction was 1: 2.5 in soil / water suspension Jackson (1958), total salt 1: 2.5 soil / water suspension in Richards ( 1954) with the electric conductivity meter lime with Scheibler calcimeters (Hizalan and Ünal, 1966), organic matter modified Walkley Black method (Walkley and Black, 1934), total nitrogen Bremner (1965), available phosphorus by sodium bicarbonate method (Olsen et al., 1954), the coloring was determined in blue and the sludge samples and colored with Barton yellow color method (Kacar, 1984). Exchangeable potassium in soil and sewage sludge by shaking of $1 \mathrm{~N}$ ammonium acetate (Thomas 1982) and the extracts were determined by microwave plasm (MPAES) atomic emission spectrophotometer (Table $1)$.

\section{MATERIALS and METHODS}

Table 1. Some physical and chemical properties of soil and sludge used in the experiment

Cizelge 1. Denemede kullanılan arıtma çamuru ve toprăğn bazı fiziksel ve kimyasal özellikleri

Sewage sludge properties (Arıtma çamuru özelliklerı)

\begin{tabular}{ll}
\hline Soil properties (Toprak özelliklerı) & \\
\hline Clay, Kil (\%) & 62.04 \\
Silt, Silt (\%) & 25.00 \\
Sand, Kum (\%) & 12.96 \\
Texture, Tekstür & Killi \\
pH (1:2.5 water) & 7.76 \\
Salt, Tuz ( $\mu$ s/cm) & 967.5 \\
Lime, Kireç (\%) & 13.19 \\
Organic mat.,Organik mad.(\%) & 1.71 \\
N, Azot (\%) & 0.13 \\
Available P, Alınabilir P (mg/kg) & 12.74 \\
Exchangeable K, Değişebilir K (mg/kg) & 584.0
\end{tabular}

According to the analytcal data, the trial soil is clayey structure, slightly alkaline reaction, unsalted, highly calcareous, organic matter content in the middle, nitrogen and phosphorus content is sufficient, potassium content is high. The $\mathrm{pH}$ of the treatment sludge used in the study is slightly acidic, extremely highly salty, high in organic matter content, nitrogen and phosphorus contents are found high with very high potassium content.

The experiment was carried out as four replicates, according to the trial design of random plots, in a total

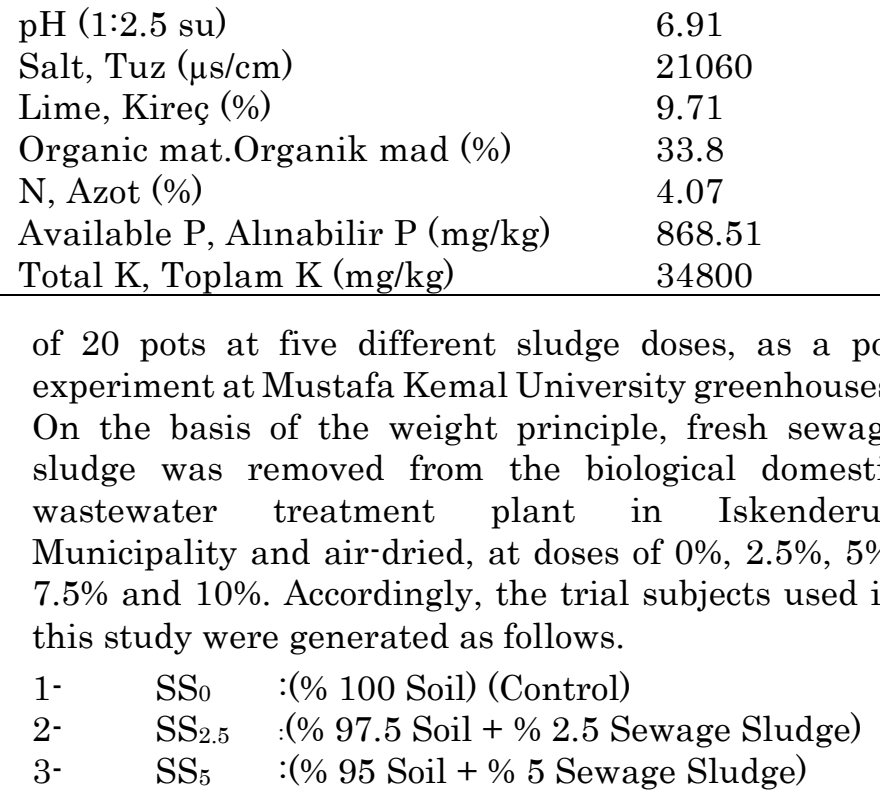




\section{$4^{-} \quad \mathrm{SS}_{7.5} \quad:(\% 92.5$ Soil + \% 7.5 Sewage Sludge $)$}

$5^{-} \quad \mathrm{SS}_{10} \quad:(\% 90$ Soil + \% 10 Sewage Sludge $)$

After adding air-dried sewage sludges to the experimental soil, it was allowed to incubate for approximately 50 days by irrigating with pure water. After the incubation period of eight seeds were sown in the pots and irrigated with distilled water. On the 3rd day of sowing, the first germination was observed and germination was completed on the 8th day and four plants were left in the each pot. Basic dressings was applied to each pot in the form of $100 \mathrm{mg} \mathrm{kg}^{-1} \mathrm{~N}, 40 \mathrm{mg}$ $\mathrm{kg}^{-1} \mathrm{P}$ and $40 \mathrm{mg} \mathrm{kg}^{-1} \mathrm{~K}$ in $18+18+18$ fertilizers. During the experiement, the plants were irrigated with pure water and the experiment was terminated on the fortyeighth day after seed sowing. The data obtained from the study was subjected to analysis of variance using the SPSS-22 statistical package program, significant effects on the average present application are grouped according to Duncan's multiple range test.

\section{RESULTS and DISCUSSION}

Effects of sewage sludge on some physical and chemical properties of soil after the harvest

The effects of soil $(\mathrm{pH})$ on the $\mathrm{pH}$, salt, lime and organic matter content of the treated sewage sludge applied to experimental soils with the subsequent statistical evaluations are given in Table 2 . As can be seen from the analysis of the table, the effects of soil sewage sludge treatments on $\mathrm{pH}$, total salt, lime and organic matter contents were found to be significant $(\mathrm{P}<0.01)$. While the soil's average $\mathrm{pH}$ and lime content showed a linear gradual decrease by the effect of the treatment sewage sludge applied to the soil in the gradually increasing doses, a linear gradual increase was observed in the mean salt and organic matter contents of the soil. The highest value measured in average $\mathrm{pH}$ values with the application of increased sewage sludge was found in the control application $\left(\mathrm{SS}_{0}\right)$ in which the treatment sludge was not applied with 7.81 , followed by an $\mathrm{SS}_{5}$ dose of 7.80 to $\mathrm{SS}_{2.5}$ and 7.74, and these three applications were included in the same Duncan group. The applications of $\mathrm{SS}_{7.5}$ and $\mathrm{SS}_{10}$ were taken into different Duncan groups by taking $\mathrm{pH}$ values of 7.63 and 7.25, respectively (Table 2). Different results were found in the studies conducted in different places related to the subject. For example, Bozkurt et al. (2001) reported that the effect of increasing sludge doses on soil $\mathrm{pH}$ was not significant as a nitrogen source in winter barley. Snyman et al. (1998) reported that the effects of treatment sludge on the $\mathrm{pH}$ of soil are significant. This could be explained by the difference in the physical and chemical properties of the different sewage sludge and treated soil.

With increasing amounts of soil treatment sludge applications, a linear increase has occurred in the average salt content of the soil. The salt content of $\mathrm{SS}_{0}$, $\mathrm{SS}_{2.5}, \quad \mathrm{SS}_{5}$ and $\mathrm{SS}_{7.5}$ applications to soil were determined as 596.00, 655.25, 721.38 and 924.13 $\mu \mathrm{S} / \mathrm{cm}$ respectively and all of them were in the same Duncan group. However, the salt content of the soil applied by sewage sludge at the highest rate was $\mathrm{SS}_{10}$ $2555.00 \mu \mathrm{s} / \mathrm{cm}$, and was determined as a different group from all others where the salt level reached to the highest average value in the Duncan test (Table 2).

Significant decreases in the lime content of the soil were determined by increasing Sewage sludge applications in soil. The highest content of lime without sewage sludge treatment was determined as $12.86 \%$ by $\mathrm{SS}_{0}$ treatment being in the same Duncan group with in $12.62 \%$ by $\mathrm{SS}_{2.5}$ treatment followed by $12.54 \%$ by $\mathrm{SS}_{5}, 11.96 \%$ by $\mathrm{SS}_{7.5}$ and $11.22 \%$ by $\mathrm{SS}_{10}$ ones as percentage values in the order of linearly decreasing direction. However the reverse was the case for the organic matter contents starting with $1.78 \%$ as the lowest value up to the highest value of $2.92 \%$ in the order of gradually increasing direction by the treatments in the same order (Table 2). That is consistent with findings of many researchers of soil organic matter increase by sewage sludge treatment (Mantovi et al., 2005; Demir \& Çimrin, 2011). On the other hand, sewage sludge applications resulted in similar trends in many studies in terms of increasing the salt and organic matter content of the soil but reducing the content of $\mathrm{pH}$ and lime (Unal and Katkat, 2003; Angin and Yaganoglu, 2009; Çiçek et al. 2013).

\section{Application of Corn Yield and Plant Height and Diameter Effects:}

Increasing sewage sludge treatment to the soils affected significantly fresh root and shoot and, dry shoot weight at $\mathrm{P}<0.001$, while on the root dry weights at $\mathrm{P}<0.01$ level was statistically significant.

When the effect of sewage sludge on fresh root and shoot weights was examined, it was observed that all applications increased the yield gradually according to the witness but there were statistically insignificant decrements in the increases in question starting by $\mathrm{SS}_{7.5}$ treatment for fresh root weight but the statistically significant decrease for dry root weight by $\mathrm{SS}_{10}$ treatment. Nevertheless, statistically significant yield decrease for fresh and dry shoot weights were determined by the $\mathrm{SS}_{10}$ treatment but statistically insignificant decrease started by $\mathrm{SS}_{5}$ treatment for dry shoot weight (Table 3). That indicates the changing toxicity effect starting point of treatments independent from each other to decrease yield.

Fresh root weights of corn plants obtained from witness application $\left(\mathrm{SS}_{0}\right)$ with the lowest yield value of $6.98 \mathrm{~g}$ increased statistically significantly with increasing doses by $\mathrm{SS}_{2.5}$ as the value of $9.42 \mathrm{~g}$ and by $\mathrm{SS}_{5}$ as the value of $11.30 \mathrm{~g}$ but insignificant decreases were determined in the increases in question at the following doses by $\mathrm{SS}_{7.5}$ treatment as the value of 10.90 $\mathrm{g}$ and $\mathrm{SS}_{10}$ treatment as the value of $9.42 \mathrm{~g}$. (Table 3 ). 
Table 2. Mean values of soil, $\mathrm{pH}$, salt, lime and organic matter contents of sewage sludge applications and Fcan with Duncan groups showing the difference between standard errors and averages

Cizelge 2. Arıtma çamuru uygulamalarının topră̆ın $\mathrm{pH}$, tuz, kireç ve organik madde içeriklerine ait ortalama değerleri ile standart hataları ve ortalamalar arasındaki farkı gösteren Duncan grupları ile önem düzeyleri

\begin{tabular}{lcccc}
\hline $\begin{array}{l}\text { Treatment, } \\
\text { Uygulamalar }\end{array}$ & $\mathrm{pH}$ & $\begin{array}{c}\text { Salt, Tuz } \\
(\mu \mathrm{S} / \mathrm{cm})\end{array}$ & $\begin{array}{c}\text { Lime, Kireç } \\
(\%)\end{array}$ & $\begin{array}{c}\text { Organic matter, } \\
\text { Organik mad. }(\%)\end{array}$ \\
\hline Sewage Sludge (Arttma çamuru (SS, \%)) & & & \\
\hline $\mathrm{SS}_{0}$ & $7.81 \pm 0.01 \mathrm{a}$ & $596.00 \pm 53.18 \mathrm{~b}$ & $12.86 \pm 0.29 \mathrm{a}$ & $1.78 \pm 0.06 \mathrm{c}$ \\
$\mathrm{SS}_{2.5}$ & $7.80 \pm 0.02 \mathrm{a}$ & $655.25 \pm 106.14 \mathrm{~b}$ & $12.62 \pm 0.14 \mathrm{a}$ & $2.32 \pm 0.06 \mathrm{~b}$ \\
$\mathrm{SS}_{5}$ & $7.74 \pm 0.03 \mathrm{a}$ & $721.38 \pm 33.78 \mathrm{~b}$ & $12.54 \pm 0.08 \mathrm{ab}$ & $2.43 \pm 0.07 \mathrm{~b}$ \\
$\mathrm{SS}_{7.5}$ & $7.63 \pm 0.06 \mathrm{~b}$ & $924.13 \pm 68.88 \mathrm{~b}$ & $11.96 \pm 0.16 \mathrm{~b}$ & $2.90 \pm 0.05 \mathrm{a}$ \\
$\mathrm{SS}_{10}$ & $7.25 \pm 0.03 \mathrm{c}$ & $2555.00 \pm 265.82 \mathrm{a}$ & $11.22 \pm 0.22 \mathrm{c}$ & $2.92 \pm 0.08 \mathrm{a}$ \\
\hline F values & $45.05^{* * *}$ & $37.82^{* * *}$ & $11.46^{* * *}$ & $50.08^{* * *}$ \\
\hline
\end{tabular}

$\mathrm{a}, \mathrm{b}, \mathrm{c}$ : the difference between the values shown in the same letter $(\mathrm{P}>0.05)$

$* * *$ With the $\mathrm{F}$ values were significant at the level of $0.1 \%$

Table 3. Treatment of sludge treatment corn plant root and shoot fresh and dry weight of the average values with standard errors and Duncan group and $\mathrm{F}$ values indicating the difference between the averages.

Çizelge 3. Arıtma çamuru uygulamalarının mısır bitkisinin kök ve sürgün taze ve kuru, ağırlıklarına ait ortalama değerleri ile standart hataları ve ortalamalar arasındaki farkı gösteren Duncan grupları ile önem düzeyleri

\begin{tabular}{|c|c|c|c|c|}
\hline $\begin{array}{l}\text { Treatment, } \\
\text { Sewage sludge, } \\
\text { Aritma çamuru } \\
\text { (SS) } \\
\end{array}$ & $\begin{array}{c}\text { Fresh root } \\
\text { Weight, Taze } \\
\text { kök ağırlığ } \\
\text { (g/plant) } \\
\end{array}$ & \begin{tabular}{l}
\multicolumn{1}{c}{ Dry root } \\
Weight, Kuru \\
kök ağırlığ \\
(g/plant) \\
\end{tabular} & $\begin{array}{l}\text { Fresh shoot } \\
\text { Weight, Taze sürgün } \\
\text { ağırlığ } \\
\text { (g/plant) }\end{array}$ & $\begin{array}{l}\text { Dry shoot } \\
\text { Weigh, Kuru sürgün } \\
\text { ağırlığ } \\
\text { (g/plant) }\end{array}$ \\
\hline$\overline{\mathrm{SS}_{0}}$ & $6.98 \pm 0.56 \mathrm{~b}$ & $0.87 \pm 0.07 \mathrm{c}$ & $19.55 \pm 1.34 \mathrm{c}$ & $2.89 \pm 0.22 \mathrm{c}$ \\
\hline $\mathrm{SS}_{2.5}$ & $9.42 \pm 0.43 \mathrm{a}$ & $1.09 \pm 0.04 \mathrm{a}$ & $41.18 \pm 0.96 \mathrm{ab}$ & $4.86 \pm 0.12 \mathrm{a}$ \\
\hline $\mathrm{SS}_{5}$ & $11.30 \pm 0.77 \mathrm{a}$ & $1.22 \pm 0.04 \mathrm{a}$ & $42.12 \pm 3.58 \mathrm{ab}$ & $4.64 \pm 0.35 \mathrm{a}$ \\
\hline $\mathrm{SS}_{7.5}$ & $10.90 \pm 0.78 \mathrm{a}$ & $1.06 \pm 0.09 \mathrm{ab}$ & $45.46 \pm 2.05 \mathrm{a}$ & $4.60 \pm 0.28 \mathrm{a}$ \\
\hline $\mathrm{SS}_{10}$ & $9.42 \pm 0.28 \mathrm{a}$ & $0.88 \pm 0.02 \mathrm{bc}$ & $38.02 \pm 1.46 \mathrm{~b}$ & $3.80 \pm 0.14 \mathrm{~b}$ \\
\hline F Values & $7.96^{* * *}$ & $6.10^{* * *}$ & $23.93 * * *$ & $11.54^{* * *}$ \\
\hline
\end{tabular}

$\mathrm{a}, \mathrm{b}, \mathrm{c}$ : the difference between the values shown in the same letter $(\mathrm{P}>0.05)$

The $\mathrm{F}$ values indicated by $* *$ and $* * *$ are significant at $1 \%$ and $0.1 \%$, respectively.

When the Duncan test was carried out, the $\mathrm{SS}_{0}$ treatment of fresh root weights were in a group while all others were in a different group of Duncan (Table 3). Corn plant root dry weight of $0.87 \mathrm{~g}$ was minimum for treatment of $\mathrm{SS}_{0}$. However, $\mathrm{SS}_{2.5}$ and $\mathrm{SS}_{5}$ treatments increased the dry root weights but $\mathrm{SS}_{7.5}$ and $\mathrm{SS}_{10}$ treatments resulted in the decrements in the yield increases obtained. Duncan analysis showed that the root dry weight were also create a situation similar to the fresh root weight (Table 3). When the effects of sewage sludge on various plants are examined in different studies, similar results have been reported in many studies. For example, Çimrin et al. (2000), Triple Super Phosphate and sewage sludge combinations as a source of phosphorus to a soil application resulted in the significant increase for plant dry weight compared to the control application. It was reported by Önal et al. (2003) in the study called as the effect of urban sludge applied to soil in tomato plants that plant growth, improvement of fruit properties and fruit mineral content, dry matter weight and yield values increased by increasing amount of applied sludge doses. On the other hand, in some studies, the effects of treatment sludge on root age and dry weight were significant, while in others it was insignificant. For example, Bozkurt et al. (2000) applied a increasing dose of sludge and a single dose of humic acid to the maize plant grown in calcareous soil. They reported that the root dry weight of corn plant increased with increased sludge applications. Turkmen et al. (2001) in their study on the effect of urban sewage sludge on cucumber output and seedling development, reported that applications have a positive effect on root age and root dry weights. Demir and Çimrin (2011) by sludge and humic acid application on development of corn development of corn reported that nutrient and heavy metal contents with some soil of sludge applied at increasing doses resulted significant increase in fresh and dry root weight. Akat et al. (2017), the effect of sludge treatment on root growth weight, plant growth, flowering and quality in cut rose cultivation were not found to be statistically significant, while the effect on root dry weight was found to be statistically significant. 
When the effect of the treatment of sewage sludge on fresh shoot weights is evaluated, it can be seen that according to the witness, all applications increase the weight of fresh shoots but the fresh shoot weights decrease after the application of $7.5 \%$ Sewage sludge treatment (Table 3). While the corn plant is obtained from the control application $\left(\mathrm{SS}_{0}\right)$ with the lowest fresh shoot weight value of $19.55 \mathrm{~g}$, fresh shoot weights increased by increasing doses linearly by $\mathrm{SS}_{2.5}$ treatment as the yield value of $41.18 \mathrm{~g}$ by the $\mathrm{SS}_{5}$ treatment as the yield value of $42.12 \mathrm{~g}$ and by $\mathrm{SS}_{7.5}$ treatment as the yield value of $45.46 \mathrm{~g}$ by the increasing doses but decreased as the yield value of $38.02 \mathrm{~g}$ at the last increased dose of $\mathrm{SS}_{10}$ treatment. In the Duncan analysis, the witness $\left(\mathrm{SS}_{0}\right)$, who had no treatment of Sewage sludge was in a separate group while the others were in a different group of Duncan. When the dry weight of the shoots in Table 3 is evaluated, all applications according to the control (witness) have increased the dry weight of the shoots, similar to the fresh shoot weights. However, as different from the fresh shoot weights, it is seen that root dry weights decrease after application of $2.5 \%$ sewage sludge (Table 3). In the Duncan analysis, a total of three groups were formed, the witness $\left(\mathrm{SS}_{0}\right)$ and the highest treatment sludge applications $\left(\mathrm{SS}_{10}\right)$ were formed in two different groups while all other applications $\left(\mathrm{SS}_{2.5}, \mathrm{SS}_{5}\right.$ and $\left.\mathrm{SS}_{7.5}\right)$ were included in the same Duncan group. While the dry shoots of corn plants were obtained from the witness application $\left(\mathrm{SS}_{0}\right)$ as the lowest value of $2.89 \mathrm{~g}$, the doses lead to increase to the value of $4.86 \mathrm{~g}$ at the dose of $\mathrm{SS}_{2.5}$ that after that increase the declines in the increase took place for the other treatments and after that increased compared to the other doses $\left(\mathrm{SS}_{5}, 4.64 \mathrm{~g} ; \mathrm{SS}_{7.5}, 4.60 \mathrm{~g}\right.$ and $\mathrm{SS}_{10}, 3.80 \mathrm{~g}$ ) (Table 3). Similar results have been reported by many researchers studying with different plant and sewage sludge (Bozkurt et al 2000; Çimrin et al 2000; Demir ve Çimrin 2011; Akat et al 2015; Akat et al 2017).

On the other hand, it is seen that sewage sludge applications develop the upper ground component rather than underground part of the plant. This can be attributed to the advantage of adding some nutrients to the soil by the treatment sludge, by adding salt and heavy metals to the soil, which in turn leads to the comparable loss yield in the underground part. As a matter of fact, Cimrin et al. (2000), despite the increase in the concentration of available phosphorus in the soil by treatment Sewage sludge applications, the plant's phosphorus need was not provided with sewage sludge reported. In summary, the study showed that while the sludge and TSP combinations and $80 \mathrm{mg} / \mathrm{kg}$ sludge applications significantly increased the phosphorus content of the corn plant according to the witness but the content decreased as the amount of treatment sludge increased.

Variance analysis results of the effects of increasing sewage sludge applications on plant height and plant diameter of maize plant are given in Table 4 .

Table 4. Treatment of sewage sludge on corn plant height and diameter values of the mean values with standard errors and Duncan group and $\mathrm{F}$ values indicating the difference between means

Cizelge 4. Arıtma çamuru uygulamalarının mısır bitkisi bitki boy ve çap ortalama değelerinin standart hataları ve ortalamalar arasındaki farkı gösteren Duncan grupları ile önem düzeyleri

\begin{tabular}{|c|c|c|}
\hline Treatment (Uygulamalar) & Plant height (Bitki boyu $(\mathrm{cm})$ & Plant diameter (Bitki çapı $(\mathrm{mm})$ \\
\hline \multicolumn{3}{|c|}{ Sewage sludge SS (\%) (Arıtma Çamuru) } \\
\hline$\overline{\mathrm{SS}_{0}}$ & $93.65 \pm 2.99 \mathrm{c}$ & $5.79 \pm 0.18 \mathrm{~b}$ \\
\hline $\mathrm{SS}_{2.5}$ & $110.78 \pm 1.18 \mathrm{a}$ & $8.16 \pm 0.12 \mathrm{a}$ \\
\hline $\mathrm{SS}_{5}$ & $107.62 \pm 3.79 \mathrm{ab}$ & $8.74 \pm 0.40 \mathrm{a}$ \\
\hline $\mathrm{SS}_{7.5}$ & $108.75 \pm 1.70 \mathrm{a}$ & $8.73 \pm 0.26 \mathrm{a}$ \\
\hline $\mathrm{SS}_{10}$ & $100.50 \pm 1.44 \mathrm{bc}$ & $8.66 \pm 0.09 \mathrm{a}$ \\
\hline F Values & $8.44^{* * *}$ & $28.14^{* * *}$ \\
\hline
\end{tabular}

$\mathrm{a}, \mathrm{b}, \mathrm{c}$ : the difference between the values shown in the same letter $(\mathrm{P}>0.05)$

$* * *$ With the $\mathrm{F}$ values were significant at the level of $0.1 \%$

The effect of treatment sewage sludge doses on the plant height and plant diameter of the corn plant was statistically significant at $0.1 \%$. According to the plant height in Table 4 , it is seen that all applications increase the plant height according to the witness $\left(\mathrm{SS}_{0}\right)$, but the highest plant height was obtained by $2.5 \%$ sewage sludge treatment as seen in the same Duncan groub. Corn plant height was obtained from control application $\left(\mathrm{SS}_{0}\right)$ with a minimum value of $93.65 \mathrm{~cm}$ and increased to $110.78 \mathrm{~cm}$ at $\mathrm{SS}_{2.5}$ dose. In all other doses, slight decreases in the increase in question were obtained compared to the control treatment $\left(\mathrm{SS}_{5}, 107.62 \mathrm{~cm} ; \mathrm{SS}_{7.5}, 108.75 \mathrm{~cm}\right.$ ve $\mathrm{SS}_{10}$, $100.50 \mathrm{~cm}$ ). The corn plant was obtained from control application $\left(\mathrm{SS}_{0}\right)$ with the lowest plant diameter of 5.79 $\mathrm{mm}$, while the diameter of the plant increased $\left(\mathrm{SS}_{2.5}\right.$, $\left.8.16 \mathrm{~mm} ; \mathrm{SS}_{5}, 8.74 \mathrm{~mm} ; \mathrm{SS}_{7.5}, 8.73 \mathrm{~mm} ; \mathrm{SS}_{10}, 8.66 \mathrm{~mm}\right)$ with increasing doses compared to the control treatment. Similarly, Turkmen et al. (2001) reported the effects of urban sewage sludge with the positive effect on growth and seedling development in a study on the shoot and root size with. Demir and Çimrin 
(2011) reported in a study about the development of corn plant by application of sludge and humic acid on nutrient and heavy metal contents and some soil properties that increasing the amount of applied sewage sludge increases the plant height significantly. Akat et al. (2015) studied on Limonium sinuatum compindi white flower variety as plant material on growth, yield and quality of by the treatment of sewage sludge including the length and thickness of flower stalks and it was reported that there were significant effects on control.

As a result, in the study conducted with fresh sludge from the domestic biological treatment plant in the district Iskenderun of province Hatay, although the treatment sludge applications have positive effects on some plant properties, there were reverse effects such as increased salinity with decreased the $\mathrm{pH}$ and lime content in the soil indicate that it is not appropriate to use this treatment sludge directly in agricultural soils..

\section{ACKNOWLEDGEMENTS}

This work was supported by the [Mustafa Kemal University Scientific Research Projects Coordinator] under Grant [Project Number 15880].

\section{Statement of Conflict of Interest}

Authors have declared no conflict of interest.

\section{Author's Contributions}

The contribution of the authors is equal.

\section{REFERENCES}

Akat H, Cetinkale Demirkan G, Akat Ö, Yağmur B, Yokaş İ 2015. Effects of Sewage Sludge Applications on Plant Growth, Yield and Flower Quality of Limonium. Ege Üniversitesi Ziraat Fakültesi Dergisi, 52(1): 107-114.

Akat H, Altunlu H, Çetinkale Demirkan G, Akat Ö, Saraçoğlu Ö A, Yokaş I 2017. Effect of Sewage Sludge Application on Plant Development, Flowering and Quality of Cut Rose Cultivation. Ege Üniversitesi Ziraat Fakültesi Dergisi, 54(3): 327332 .

Angin İ, Yağanoğlu AV 2009. Application of Sewage Sludge as a Soil Physical and Chemical Amendment, Ekoloji Çevre Dergisi, 19(73): 39-47.

Aşık B B, Katkat AV 2004. Possibilities of the Usage of Food Industry Treatment Waste (sludge) for Agricultural Area Purposes. Uludağ Üniversitesi Ziraat Fakültesi Dergisi, 18(2): 59-71.

Ayvaz Z 2000. Evaluation of Sewage Sludge. Ekoloji Çevre Dergisi, 9(35): 3-12.

Belhaj D., Elloumi N, Jerbi B, Zouari M, Abdallah FB, Ayadi H, Kallel M 2016. Effects of Sewage Sludge Fertilizer on Heavy Metal Accumulation and Consequent Responses of Sunflower (Helianthus annuus). Environmental Science and Pollution
Research, 23(20):20168-20177.

Bouyoucous GD 1951. A Recablibration of the Hydrometer Method for Making Mechanical Analysis of the Soil. Agronomy Journal, 43 434-438.

Bozkurt MA, Erdal İ, Çimrin KM, Karaca S, Sağlam M 2000. Kentsel Aritma Çamuru ve Hümik Asit Uygulamalarının Mısır Bitkisinin Besin İçeriği ve Ağır Metal Kapsamına Etkisi. Tarım Bilimleri Dergisi, 6(4): 35-43.

Bozkurt MA, Yılmaz I, Çimrin KM 2001. Kentsel Arıtma Çamurunun Kışlık Arpada Azot Kaynağı Olarak Kullanılması. Yüzüncü Yıl Üniversitesi Ziraat Fakültesi, Tarım Bilimleri Dergisi, 7(1): 105110.

Bremner JM 1965. Total nitrojen. in. C.A. Black et al. (ed). Methods of Soil Analysis. Part 2. Agronomy 9; 1149 - 1178. Am. Soc. of Agron., Inc. Madison, Wisconsin, USA.

Çelik A, Ünal M, Kutlu T 2009. Sera Koşullarında Arıtma Çamuru Uygulamalarının freesia spp' nin Çiçeklenme Özelliklerine Etkileri. Selçuk Üniversitesi Selçuk Tarım ve Gıda Bilimleri Dergisi, 23(49): 50-54.

Çetinkale Demirkan G, Akat H, Yokaş İ 2014. Atık Su Arıtma Çamurunun clarkia amonena (Yer Açelyası) Türünde Bitki Gelişimi ve Çiçeklenme Üzerine Etkisi. U. Ü. Ziraat Fakültesi Dergisi, 28(2): 49-57.

Çetinkale Demirkan G, Akat H, Yağmur B 2017. Farklı Atık Materyallerin Matthiola incana 'Iron Rose' Yetiştiriciliğine Etkisi. Mediterranean Agricultural Sciences, 30(3): 173-178.

Çiçek A., Karaman MR, Turan M, Güneş A, Çiğdem A 2013. Yield and Nutrient Status of Wheat Plant (T. Aestivum) Influence by Municipal Wastewater Irrigation. Journal of Food, Agriculture \& Environment, 11 (1); 733-737.

Çimrin K M, Bozkurt MA, Erdal İ 2000. Kentsel Arıtma Çamurunun Tarımda Fosfor Kaynağ Olarak Kullanılması. Yüzüncü Yıl Üniversitesi Ziraat Fakültesi, Tarım Bilimleri Dergisi, 10(1): 8590.

Delgado Arroyo MDM, Porcel Cots MA, Miralles De Imperial Hornedo $R$, Beltran Rodriguez EM, Beringola Beringola L, artin Sanchez JV 2002. Sewage Sludge Compost Fertilizer Effect on Maize Yield and Soil Heavy Metal concentration. Revista Internacional de Contaminationacion Ambiental, 18(3): 147-150.

Demir E, Çimrin K M 2011. Arıtma Çamuru ve humik Asit Uygulamalarının Mısırın Gelişimi, Besin Elementi ve Ağır Metal İçerikleri ile Bazı Toprak Özelliklerine Etkileri. Tarım Bilimleri Dergisi, 17: 204-216.

Düzgüneş O, Kesici T, Kavuncu O, Gürbüz F, 1987. Araştırma ve Deneme Metodları (İstatistik Metodları-II). Ankara Üniversitesi Ziraat Fakültesi Yayınları: 1021, Ankara, 381 s. 
Hizalan E, Ünal E 1966. Topraklarda Önemli Analizler. Ankara Üniversitesi Ziraat Fakültesi Yayınları: 278.

Jackson M 1958. Soil Chemical Analysis. Prentice Hall, Inc. New Jersey. USA.

Kacar B 1984. Bitki Besleme Uygulama Kılavuzu. Ankara Üniversitesi Ziraat Fakültesi Yayınları: 900, Uygulama Kılavuzu: 214, Ankara, 140 s.

Küçükhemek M, Gür K, Uyanöz R 2008. Toprağa Uygulanan Arıtma Çamuru, Ahır Gübresi ve Karışımlarının, Çim Bitkisinin Bazı Makro-Mikro Besin Elementleri ve Verimi Üzerine Etkisi. Selçuk Üniversitesi Ziraat Fakültesi Dergisi, 22(45): 94104.

Mantovi P., Baldoni G, Toderi G, Research W 2005. Reuse of Liquid, Dewatered, and Composted Sewage Sludge on Agricultural Land: Effects of Long-term Application on Soil and Crop. Water Research. 39: 289-296.

Olsen SR, Cole V, Watanabe FS, Dean LA 1954. Estimations of Available Phosphorus in Soils by Extractions with Sodium Bicarbonate. U. S Dept. Of Agric. Cric. 939.

Önal MK., Topçuoğlu B, Arı N 2003. Toprağa Uygulanan Kentsel Arıtma Çamurunun Domates Bitkisine Etkisi. II. Gelişme ve Meyve Özellikleri ile Meyvede Mineral İçerikleri. Akdeniz Üniversitesi Ziraat Fakültesi Dergisi, 16(1): 97-106.

Özyazıcı MA, Özyazıcı G 2012. Arıtma Çamurunun Toprağın Bazı Temel Verimlilik Parametreleri Üzerine Etkileri. Anadolu Tarım Bilimleri Dergisi, 27(2): 101-109.

Özyazıcı MA, Özyazıcı G, Bayraklı B 2012. Arıtma Çamuru Uygulamalarının Toprağın Ekstrakte Edilebilir Demir, Bakır, Çinko ve Mangan Kapsamı Üzerine Etkileri. Toprak Su Dergisi, 1(2): 110-118.

Richards LA 1954. Diagnosis and Improvement of
Saline and Alkaline Soils. Handbook: 60, U. S. Dept. of Agriculture.

Scancar J, Milacic R, Strazar M, Burica O 2000. Total Metal Concentrations and Partitioning of $\mathrm{Cd}, \mathrm{Cr}$, $\mathrm{Cu}, \mathrm{Fe}, \mathrm{Ni}$ and $\mathrm{Zn}$ in Sewage Sludge. Science of The Total Environment, 250(1-3): 9-19.

Snyman HG, De Jong JM, Aveling TAS 1998. The stabilizationof sewage sludge applied to agricultural land and the effects on maize seedlings. Wat. Sci. Tech., 38(2): 87-95.

Thomas GW 1982. Exchangeable Cations. Chemical and Microbiological Properties. Agronomy Monography. No: 9, A.S.A.-S.S.S.A., Madison, Winconsin. USA. P. 159-165.

Türkmen Ö., Şensoy S, Çırka M 2001. Kentsel Arıtma Çamurunun Hıyarda Çıkış ve Fide Gelişimi Üzerine Etkisi. Yüzüncü Yıl Üniversitesi Tarım Bilimleri Dergisi, 11(1): 1-4.

Ünal M., Katkat AV 2003. Bisküvi ve Şekerleme Sanayi Arıtma Çamurunun Toprak Özelliklerine ve Mısır Bitkisinin Kimi mineral Madde İçeriği üzerine Etkileri. Uludağ Üniversitesi Ziraat Fakültesi Dergisi, 17(1): 107-118.

Walkley A, Black LA 1934. An Examination of the Degtjareff Method for Determining Soil Organic Matter and a Proposed Modification of the Chromic Acid titration Method. Soil Sci., 37: 29-38.

Yalçın G, Yavuz R, Taşpınar K, Yılmaz M, Ateş Ö 2010. Eskişehir Atık Su Arıtma Tesislerinden Çıkan Çamurların Farklı Münavebe Sistemlerinde Kullanılması. Tarım ve Köy İşleri Bakanlığı Tarımsal Araştırmalar ve Politikalar Genel Müdürlüğü, Temmuz-2010, s:43.

Yalçın G, Yavuz R, Yılmaz M, Taşpınar K, Ateş Ö 2011. Arıtma Çamurlarının Tarım Alanlarında Değerlendirilmesi. Mühendislik ve Fen Bilimleri Dergisi, Sigma 3: 156-164. 